\title{
Considering Aesthetic Characteristics in the Master Plan of Krasnoyarsk
}

\author{
Valerii I. Krushlinskii and Olga S. Fedorova* \\ Siberian Federal University \\ 79 Svobodny, Krasnoyarsk, 660041, Russia
}

Received 12.05.2016, received in revised form 19.06.2016, accepted 27.07.2016

\begin{abstract}
The article presents the results of research and analysis of the city of Krasnoyarsk. The authors revealed attractive and comfortable places in the city, bright memorable architectural objects of modernity and history, as well as the disharmonious elements that should be neutralized. The article suggests principles for introduction of new forms into the project of the new centre and reconstruction. These principles include identification of the characteristics and commonalities of the existing architectural image, the study of features of the influence of a complex of natural and climatic factors on urban-planning and architecture, formation of the concept, principles and design methods of new ensembles and forms in harmony with the existing buildings, as well as the landscape, its dominants and other features of natural conditions. The authors examined examples of the actual project of the new centre of Krasnoyarsk made by such institutions as "KrasnnoyarskNIIproekt" and "KrasnoyarskGrazhdanproekt". The analysis of design decisions of the new centre was carried out taking into account the aesthetic characteristics of the natural environment of Krasnoyarsk.
\end{abstract}

Keywords: regional-climatic features, aesthetics, natural and climatic factors, landscape, visual connections with landscape, image of the city, aesthetically attracting territories in the city, master plan.

DOI: 10.17516/1997-1370-2016-9-8-1880-1887.

Research area: culture studies.

Siberian cities are mostly located in beautiful landscape surroundings, on an interesting and sometimes difficult terrain surrounded by mountains, near large and small rivers. There is a need to incorporate natural dominants in the structure of the city, visual and associative links emerge. All these advantages make it possible to create a unique image of each of the Siberian city, cleverly include them in the overall compositional structure of the city, and identify the best architectural and artistic qualities of the city.

To date, consideration of local conditions is limited only to the application of architectural techniques and some calculations aimed at neutralizing negative natural effects. But when we are talking about a unique image of the city, we need to carry out a compositional-spatial analysis of the location defined for construction or under reconstruction.

\footnotetext{
(C) Siberian Federal University. All rights reserved

* Corresponding author E-mail address: olga.sibiriachka@yandex.ru
} 
The cities are growing and the scale of development is changing, so there is a need for proper placement of dominants not only from a commercial point of view, but also according to the architectural and artistic image of the city.

There is a tendency towards building obviously attractive places from a commercial point of view, when their attraction often gets lost. This is construction in pine forests, birch groves, where the anthropogenic influence of humans leads to the destruction of the natural environment. It is necessary to keep the recreational areas in the city and suburbs, and expertly turn them into parks and squares. The main feature of the natural space of the cities in Siberia is their richness with various natural elements and diversity that is characterized by a variety of planting, meadows, rivers, lakes, inclusion of pine forests, natural monuments in the territory of the city (The Stolby reserve, a stream in Akademgorodok, etc.).

A questionnaire survey among residents of Krasnoyarsk and experts identified attractive and comfortable places in the city, bright memorable architectural objects of modernity and history. It also revealed the priorities of natural landscape elements in the visual field of Krasnoyarsk. When we apply these objects to the master plan of the city, we can see the real picture of distribution of aesthetic characteristics in Krasnoyarsk today, which reveals locations for placement of new objects taking into account their interaction with the identified natural dominants. This approach also helps to consider not only the visual links, but also the existing pedestrian-transport scheme.

The analysis shows that there is an agreement in selection of beautiful and comfortable places among residents and experts. It confirms that in the city, there are places that fully meet the aesthetic needs of residents and are highly appraised by experts. Most harmonious elements of construction and comfortable attractive places are concentrated in the historical centre of Krasnoyarsk (Fig. 2).

The "Stolby" Reserve, the Yenisei River, Karaul'naya Mountain remain the most significant natural dominants in formation of the image of the city. Figure 1 shows the distribution of territories that are attractive in their aesthetic qualities combined with the dominant landscape

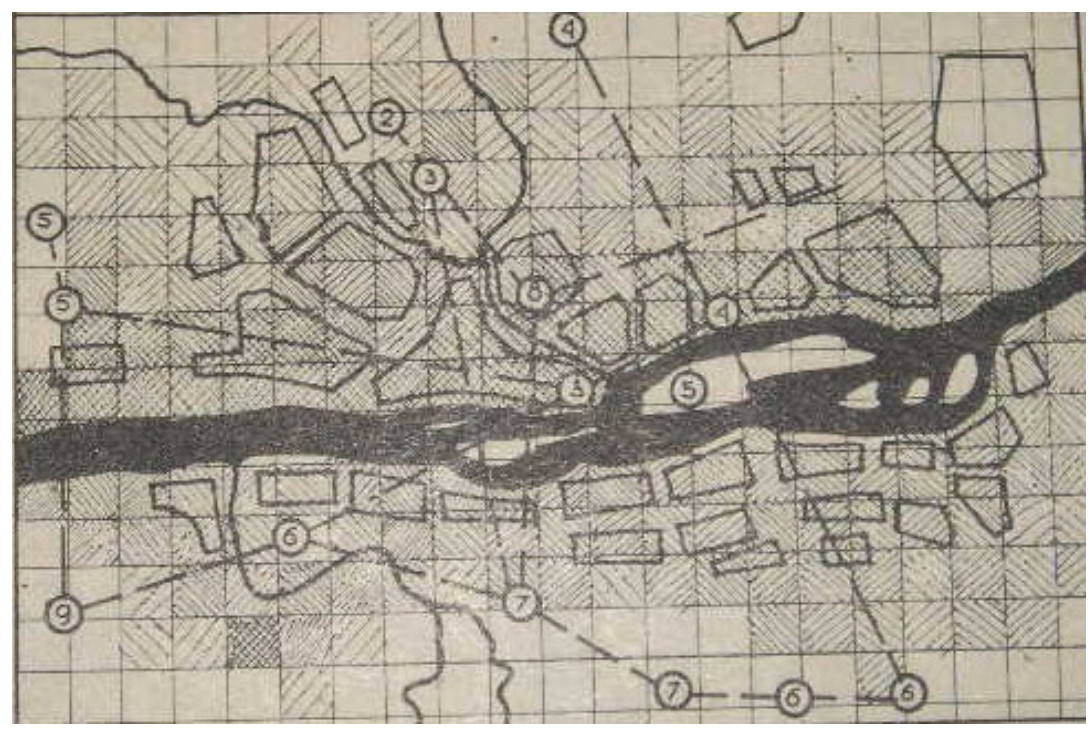

Fig. 1. Scheme of distribution of aesthetic territories in Krasnoyarsk V.I. Krushlinskii 


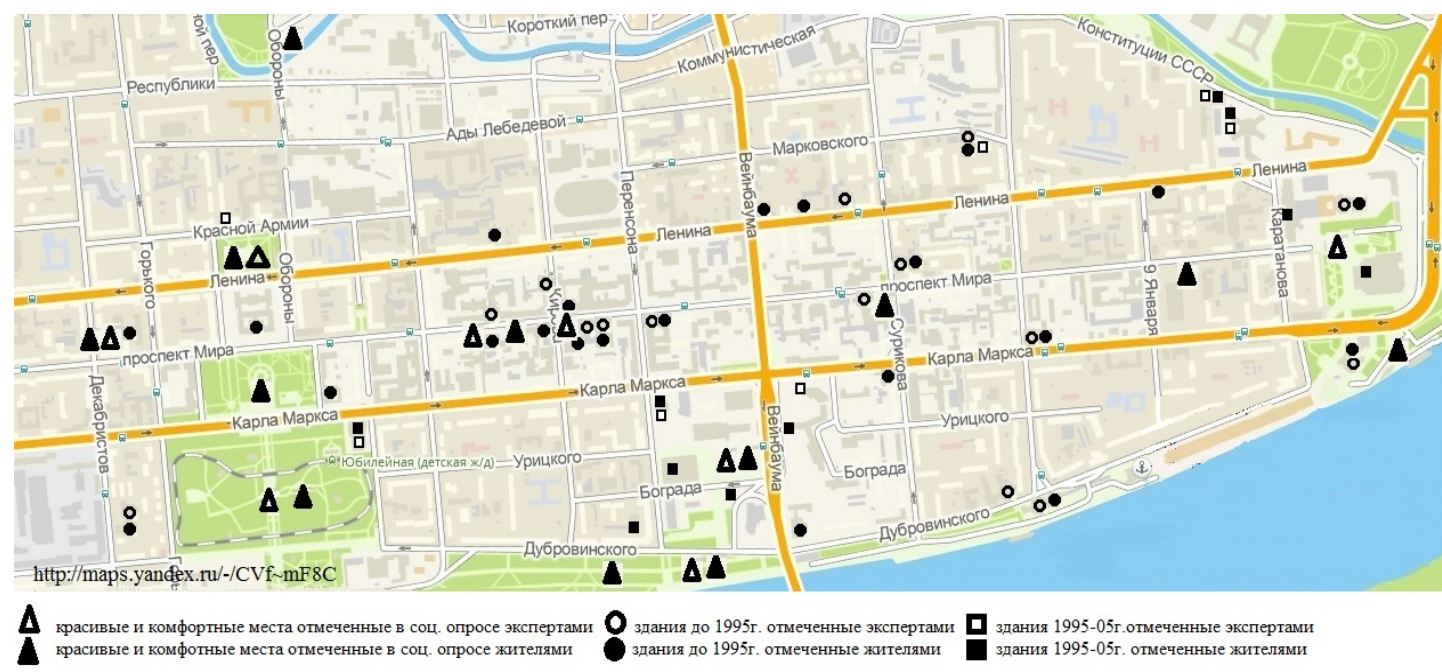

Fig. 2. Harmonious elements of construction and comfortable attractive places in the centre of Krasnoyarsk (marked in the sociological survey among residents and experts)

elements, which makes them valuable for the city. The identified areas are visible from almost all places in the city, so it is important to pay attention to building new objects in these territories by examining all the visual links with the main roads, bridges, embankment, etc.

The analysis shows that there are the same disharmonious elements in the city marked by the residents and experts. This indicates that these elements are either not in their places, have been built in an uncomfortable scale, do not bring aesthetic satisfaction, are not comfortable or safe or require careful study and remediation of the situation.

When designing the master plan of the city, the first steps in the formation of the characteristics of the artistic image of the city are made consciously or intuitively. This is the choice of the city structure, allocation of territories for the main functional areas. Here, the following spatial characteristics are important: basin feature of the mountainous terrain or the flat terrain, promenade along the river, lake or sea. Thus, we immediately can see the dominant elements of the landscape that can be fundamental in the future structure of the city. In the already established cities there is a need for a special analysis of the interaction of the city's development with the main elements of the natural landscape. This is confirmed by a centuries-long experience of placing the Orthodox churches in the dominant elements of landscape, upland areas, and high embankments in the city centre. In the master plan it is necessary to define places for the new dominant ensembles, parks, squares, boulevards, large public and residential buildings, which means it should not only be a functional urban document of the spatial planning, but also determine the future quality of the artistic image of the city in many respects.

The problems of formation of an architectural and artistic image should be of particular importance in the reconstruction projects of the centre and other planning elements. It is very important not to do much harm by introducing alien elements. The project of the new city centre or reconstruction, the development problems of the architectural and artistic image of the city are the essential aspects. The introduction of new forms should be based on the following principles:

- identification of characteristics and commonalities of the existing architectural image; 
- study of the influence of natural and climatic factors on urban planning and architecture;

- formation of the concept, principles and methods for designing new forms and ensembles in harmony with the existing buildings, as well as the landscape, its dominants and other features of the natural environment.

Let us consider an example of the real project of the new centre of Krasnoyarsk. The master plan of Krasnoyarsk that was previously developed by Lengiprogor proposed placement of a new central planning area of the city, identified prospective areas for construction at the site of the old airport. It also demonstrated inability of the existing centre to carry out the city management functions. The new centre is located at the geometric focus of the long-term development of the city, connected by high-speed highways with large industrial and residential areas and is stretched out right to the waters of the Yenisei. This major urban issue was brought on a nationwide architectural competition that was attended by many design institutes of the country. On this basis, the institute "Krasnoyarskgrazhdanproekt" made a planning design of the new centre (the architect V.I. Krushlinskii). It analyzed the architectural and artistic aspects (city environment, landscape structure in this part of the city, planting in the neighbouring areas), determined a scale of the business centre, and formed the green diameters and the correlation of the historic centre with the new one along the embankment.

The central planning area includes a vast territory of the prospective development of the left bank. The green diameters with dispersed development, urban ensembles of a public nature, sports parks, and recreation areas will be established along the highways. This decision will clearly define the planning boundaries of residential areas and bring order to the structure of the city.
Given special importance of the project of the new centre, a nationwide competition was held with the participation of the largest institutions from Moscow, St. Petersburg, Novosibirsk and Krasnoyarsk. Some decisions of contestants served as a reference base of the detailed design. However, most of the entries did not fully take into account the planning structure existing in this area, the state of the urbanplanning development problems and prospects of development of Krasnoyarsk.

- The basic urban-planning principles of the design concept are as follows:

- harmony of the structural-compositional connections of the new centre with the dominant elements of the natural landscape, the water area of the Yenisei River and scenic ostrogs of the Sayany;

- planning connection of the new centre with the existing large industrial and residential areas;

- - formation of large green diameters as part of an ecological frame of the city and powerful areas for recreational activities of the population;

- extension of the scale of the new centre, access to the embankment;

- creation of a new type of urban ensembles as a system of parks, large residential and public facilities with the possibility of the alternate development.

The architectural and artistic requirements for the project were to enrich the city with aesthetically completed urban ensembles of the new type, to create an embankment silhouette with accents of the main square, to form scenic terraces on the Yenisei embankment, to construct residential and public buildings taking into account local climatic conditions.

The functional-planning requirements for the project were to achieve planning clarity, create a pedestrian area rich with service facilities and, 
at the same time, its connection with parking lots, to equip parking lots for special individual and public transport, prospective placement of underground stations, to place objects of a regional, unique nature in the centre.

The project envisages the development of the Tatyshev Island that is adjacent to the new centre as a leisure area for citizens of the central planning area. It was planned to build a hydro park, an arboretum, a rowing canal and recreation facilities on the island. The presence of large green spaces on the island and the establishment of green diameters in a neutral planning area could improve the environment state in the city and make landscaping indicators get closer to normative. The project proposes a prospective scheme for subway construction. It provides communication corridors and subway stations within the green diameters in the busiest areas.

The core of the new centre is formed on one of the green diameters that are adjacent to the Yenisei River. It is supposed to be established from major planning complexes combined into a single compositional structure by the system of flowing areas (Fig. 3).

Buildings of the House of Soviets and the multi-storey business complex form the main Lenin square. It also includes a scientific and technical planning complex: library, CSTI, computer centre, the House of Knowledge, the Book House. This square will also include a sculptural complex, stands for rallies and demonstrations. It is planned to create a decorative pool and flowing canals with alleys.

On a high embankment of the Yenisei River planning of the core of the new centre is agreed by the youth centre and hotel complex with nonstandard services at the level of 1-3 floors. There will also be located a three-hall cinema that involves a sculptural volume solution.

Behind the main square there will be a palace and park area with the adjacent theatre

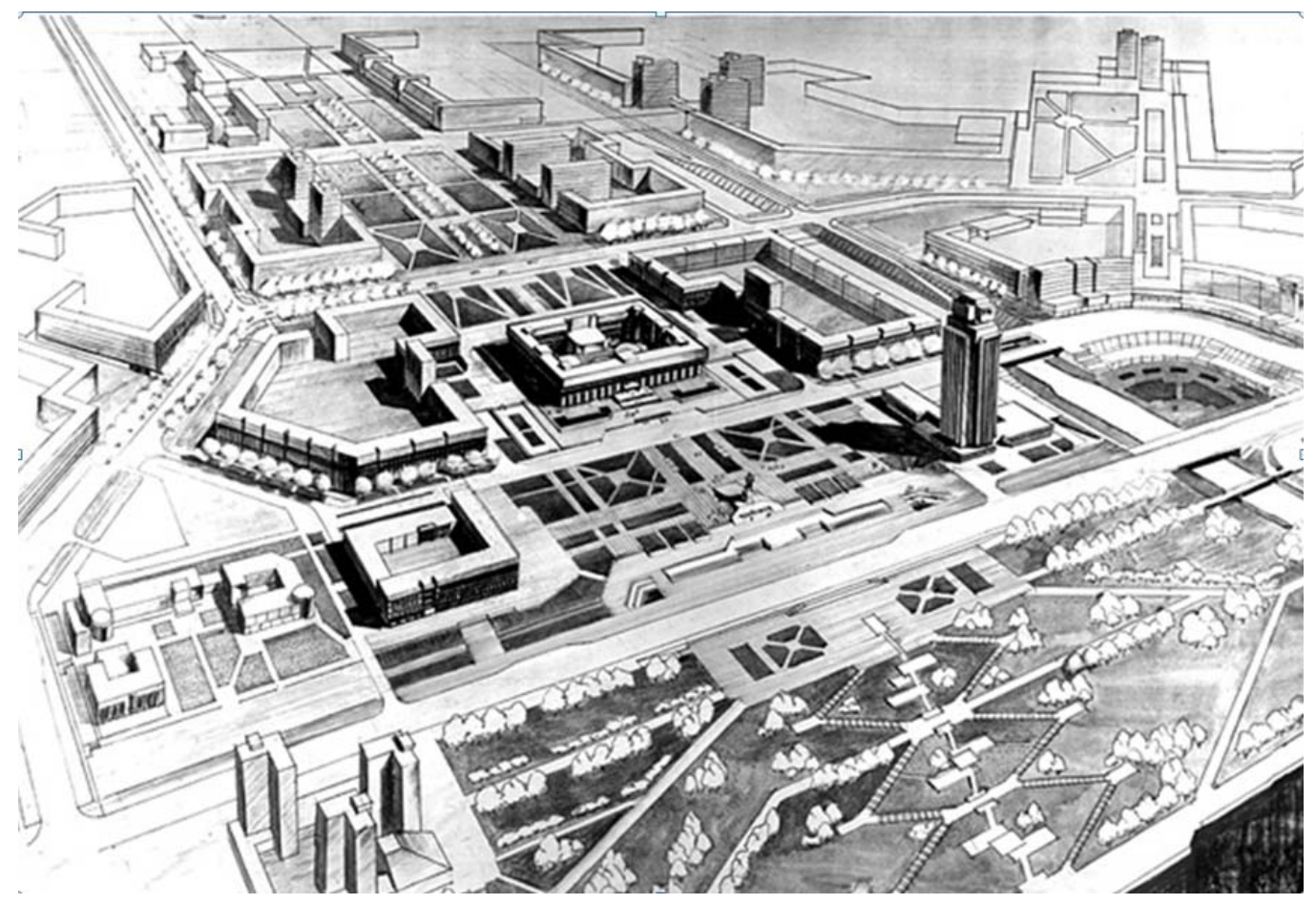

Fig. 3. Planning design of the new centre of Krasnoyarsk. Krasnoyarskgrazhdanproekt 
square, as well as a cultural and trade complex. Park areas are saturated with various recreational functions. From the embankment to the core of the new centre on the active terrain there is a system of stairs, slopes, green viewing platforms, as well as a park, a forum and a dance floor in the youth sector.

The work was carried out by a team of architects: V.I. Krushlinskii (Chief Architect of the Project), V.F. Savina, A.V. Bannikov, the Engineer E.F. Vibe. The importance of such a large-scale planning work is obvious. The project introduces a new large-scale structural unit in the development system, involves the formation of an ecological frame of the city, defines its image, orders the structure of the city in general and the perspective development of the Central District in particular. The construction of the core of the new centre has already begun: they built a bridge, highway and a transport junction, reserved areas and began the construction of residential and public buildings. Unfortunately, in the years of perestroika the green diameters have been sold for the commercial construction of standard housing and other facilities.

The planning design of the new centre and the detailed planning of the core of the new centre solved the problems of the longterm development of the city: development of new areas, development of the transport system with construction of the underground, possible deployment of industrial zones, arrangement of the existing settlement. Sketches that served as planning justifications for these projects were created on the basis of the interaction of natural and urban-planning systems.

By the beginning of the $19^{\text {th }}$ century, the historical centre of Krasnoyarsk has been established between the rivers of Yenisei and Kacha and the Trans-Siberian Railway. A place for the city's foundation was well chosen: a high bank of the Yenisei River, a pine forest, scenic mountains protecting from the wind. There was a certain planning structure, in which the two main compositional directions could be traced: from the Strelka along the Yenisei and perpendicularly to it - the deep expansion. The territory is concentrated with monuments of history, culture and architecture. The Strelka is a place of the former ostrog.

Great changes took place in the historical centre in the post-revolutionary period, and especially after the Great Patriotic War. The main squares changed their purpose; the Nativity Cathedral on the Novosobornaya Square (now - the Revolution Square) and the Cathedral of the Resurrection on the Strelka have been knocked down. The average number of floors has significantly increased; wooden buildings have been gradually getting demolished. The silhouette of the city has changed: if earlier the city was towered by churches and cathedrals, now the rest of them acquired a chamber character, and the silhouette is formed by large residential and public complexes.

The existing structure cannot withstand the onslaught of large amount of construction required for the centre of the largest city. Over time, historical buildings acquire an increasing value, and it is not just individual buildings or structures, but the developed urban environment. However, this environment cannot be frozen, it develops, and there is a functional reorientation of many buildings. This process cannot be stopped. There is a problem of management of this development, and the management process must have a clear objective: to efficiently use and timely repair everything that was built earlier, to improve urban comfort for the population and the system of the city centre. As a result of urban reconstruction of the historical centre the development is being fragmented, resulting in losing a lot of interesting buildings, a prevailing compositional structure, and connection of 
urban ensembles with the natural environment. These interrelated problems cannot be solved by traditional methods, so the project designed a methodological program and a system model of scientific and methodological studies to perform a project work consisting of the following areas:

- structural and compositional (optimization of the spatial structure in the historical centre in the city system), planning decision of a number of urban problems and the identification of the dominant historical and natural elements;

- functional and planning (improvement of functions of residential areas, service and management facilities, transport and pedestrian linkages, establishment of interconnections of the system of planning complexes, redistribution of the historic centre functions with the new centre of the city);

- architectural and artistic (establishment of an image of the historical centre, formation of completed urban-planning ensembles, improvement of the quality of architecture);

- urban-planning and environmental (environmental improvement by means of urban planning, formation of an ecological frame of the territory, organization of environment protection zones).

\section{References}

Fedorova, O.S. (2014) Vliianie prirodno-klimaticheskikh faktorov Sibiri na formirovanie arkhitekturno-khudozhestvennogo obraza goroda (na primere g. Krasnoiarska) [Influence of climatic factors of Siberia on the formation of architectural and artistic image of the city (by an example of Krasnoyarsk)]. Krasnoyarsk, Siberian Federal University Publishing House, 140 p.

Gorbachev, V.T., et al. (2011) Gradostroitel'stvo Sibiri [Urban planning of Siberia]. Ed. V.I. Tsarev, Russian Academy of Architecture and Construction Sciences, Research Institute of theory and history of architecture and urban planning. NIITIAG RAASN, Kolo, 748 p.

Iaroslavtseva, L.I. (1991) Krasnoiarskii kraeved [The Krasnoyarsk history specialist]. Krasnoyarsk, Knizhnoe izdatel'stvo, 304 p.

Kostrikin, N.D. (1977) Plan goroda kak osnova formirovaniia ego khudozhestvennogo obraza [City plan as a basis for the formation of its artistic image]. $\mathrm{PhD}$ thesis in Architecture. 18.00.01 Nikolai Kostrikin, Moscow, 25 p.
Such a program would allow us to work in all areas. A questionnaire survey has been conducted among the residents of the city and the architectural experts in order to assess quality and a city-forming role of individual buildings. On their basis, we made a planning scheme of the assessment of the quality of the architectural environment, the analysis of which allows us to draw conclusions about the prospectivity of the urban-planning reconstruction. The assessment of the environmental state in the historic centre (landscaping and pollution) allowed us to make recommendations to improve the environmental situation, remove or radically improve the production technology, quality and quantity of the environment protection planting.

As a result of the scientific and methodical work the authors developed the architectural and planning principles of the urban-planning reconstruction of the existing centre, building rules as programs of formation and development of the architectural image of the Siberian city. This will also help to creatively deflect scientific principles at the level of urban-planning design, justification of the adoption of design decisions on such complex issues of urban-planning. which will largely improve the scientific 
Krogius, V.R. (1979) Gorod i rel'ef [City and relief]. Moscow, Stroiizdat, 124 p.

Krushlinskii, V.I. (1986) Gorod i priroda Sibiri: Arkhitekturno-planirovochnye aspekty [City and nature of Siberia: Architectural and Planning Aspects]. Krasnoyarsk, KSU Publishing House, 232 p.

Krushlinsky, V.I. (2003) Litso sibirskogo goroda [Face of a Siberian city]. Krasnoyarsk, Klaretianum, 158 p.

Ruzhzhe, V.L. (1966) Krasnoiarsk. Voprosy formirovaniia i razvitiia [Krasnoyarsk. Questions of formation and development]. Krasnoyarsk, Knizhnoe izdatel'stvo, 195 p.

\title{
Учет эстетических характеристик \\ в генеральном плане города Красноярска
}

\author{
В.И. Крушлинский, О.С. Федорова \\ Сибирский федеральный университет \\ Россия, 660041, Красноярск, пр. Свободный, 79
}

В статье приведены результаты исследования и анализа территории г. Красноярска. Выявлены привлекательные и комфортные места в городе, яркие запоминающиеся архитектурные объекты современности и истории. Также показаны дисгармоничные элементы, которые необходимо нейтрализовать. Разработаны принципы для внедрения новых форм в проект нового иентра и реконструкиии - это выявление особенностей и общих черт существующего архитектурного образа, изучение особенностей влияния комплекса природно-климатических факторов на градостроительство и архитектуру, формирование концепции, принципов и приемов проектирования новых ансамблей и форм в гармонии с существующими зданиями, а также ландшафтом, его доминантами, другими особенностями природных условий. Рассмотрены примеры реального проекта нового иентра Красноярска, выполненные институтами «КрасноярскНИИпроект», «КрасноярскГражданпроект». Анализ проектного решения нового иентра сделан с учетом эстетических характеристик природного окружения г. Красноярска.

Ключевые слова: регионально-климатические особенности, эстетика, природноклиматические факторы, ландшафт, визуальные связи с ландшафтом, образ города, эстетически привлекательные территории города, генеральный план.

Научная специальность: 24.00.00 - культурология. 